\title{
Financial Closing Time, IT Capability, And Quarterly Earnings Patterns
}

Mingjun Zhou, DePaul University, USA

Miguel Aguirre-Urreta, Florida International University, USA

\begin{abstract}
This study examines whether superior Informational Technology Capability (ITC) is associated with a shorter financial closing time for publicly traded companies. We also compare patterns of late-year adjustment of quarterly earnings between ITC and non-ITC companies. ITC firms appear to have shorter financial closing times and seem to have a reduced probability to exhibit late-year earnings reversals.
\end{abstract}

Keywords: Financial Closing Time; IT Capability; Earnings Management

\section{INTRODUCTION}

nformation Technology Capabilities (ITC) represents how IT resources are adopted and deployed in the business processes of organizations to reach their strategic goals. The development of ITC can improve managerial access to operating information and the reporting of financial results. However, ITC may also assist in earnings management by allowing managers to be aware of any shortfalls before fiscal year end and use their discretions in financial reporting to "close the gap" between actual and expected operating results such as analyst earnings forecasts. In this study, we examine the effect of ITC on the length of time needed for companies to close their book and report annual earnings, which is known as the Financial Closing Time (FCT), and the quarterly earnings patterns of ITC firms.

Prior studies focused on the relationship between superior ITC and greater business performance based on accounting measures such as ROA, ROE and Tobin' q (i.e. Tam, 1998). Chae, Chang, and Prybutok (2014) argue the competitive advantages of the first-users of information technology in organizations may have eroded when ERP systems and web technologies become more standardized and available to their competitors. However, our empirical results suggest that, even with today's widespread information technology, ITC still appears to be unevenly distributed and leads to competitive advantages in terms of timely financial reporting.

We also examine the instances where management may be incentivized to develop ITC not only to meet demands for timely performance reports but also to engage in earnings management activities. In developing ITC, companies may allocate IT resources in various business processes to allow information to be gathered and discretions to be applied in a strategic manner. For example, enterprise systems can allow managers to be more precise in their internal predictions about an impending shortfall in the earnings and make manipulations before fiscal year end to avoid missing annual earnings targets. On the other hand, researchers have also shown that ITC can be effective to remediate internal control weaknesses (i.e. Chen et al. 2014) but not in reducing audit delays. To reconcile these different views, the analytical modeling in Stratopoulos, Vance and Zou (2013) suggests that the incentive effects of ITC on earnings manipulations to meet performance targets will likely outweigh the costs. We contribute to the literature by testing the empirical association between IT capability and financial closing time, and whether ITC firms are less likely to exhibit abrupt changes in quarterly earnings patterns.

Prior research on the relationship between ITC and earnings management in terms of financial reporting accruals produced mixed results. For example, Brazel and Dang (2008) find increases in discretionary accruals with ERP systems while Morris and Laksmana (2010) demonstrated a decrease in discretionary accruals following implementations of ERP systems. Shifting away from accrual measures, this study investigates the relationship between ITC and the timing and directions of quarterly earnings changes. The accounting literature has suggested that 
the shifts of directions in late-year earnings is a strong signal of manipulations by management to meet annual targets, which is also known as "last chance earnings management" (i.e. Das, Shroff, \& Zhang, 2009). On the other hand, the development of information technology such as enterprise systems may help managers to notice any shortfalls in the interim periods and take steps to avoid missing expected earnings targets at fiscal year-end. We show that firms with strong ITC have a reduced probability to exhibit fourth-quarter earnings reversals.

In summary, we find that superior organizational IT capabilities are still heterogeneously distributed after decades of rapid changes in information technology and give ITC firms a competitive advantage by reducing their financial closing time. We also examine patterns of quarterly earnings of ITC firms and suggest that the wealth-maximizing manipulation for a manager in an organization with superior IT capability is to use smaller adjustments to bring earnings in line with expectations, thus attenuating the likelihood of an occurrence of fourth-quarter earnings reversals.

\section{BACKGROUND AND HYPOTHESES}

\section{Financial Closing Time and Information Systems}

The time between fiscal year end and the earnings announcement date is defined as the Financial Closing Time (FCT). There is also a time lag between fiscal year-end and when external auditors sign off on the financial statements, which is also known as the Audit Report Lag (ARL). In Brazel and Dang (2008), FCT is shorter for companies after their implementations of Enterprise Resource Planning (ERP) software. Chen at al. (2014) measure the relationship between firms' IT capability and audit fees as well as audit delays. They find that firms with high IT capability can reduce audit fee increases but not audit delays. Under the conceptual framework of Leventis and Weetman (2004), earnings are considered "ready for release" when independent auditors finish their work and sign-off on the financial statements. But firms are as likely to release earnings before the signing of the independent audit report. Lee, Made, and Son (2008) use a sample of firms that files with the Securities Exchange Commission (SEC) and find that over $43 \%$ of the firms release earnings reports before the date of the independent audit report. This is consistent with the notion that mangers can and will exercise their discretion in financial closing time and earnings announcement. Specifically, we contribute to the literature on FCT by examining its relationship with IT Capability.

\section{IT Capability}

It is important to distinguish the difference between information technologies such as ERP software and IT Capability. Bharadwaj (2000) first proposed that "IT capability (ITC) refers to an organization's ability to effectively implement IT-based resources and combine them with its business processes" (p. 171). This is a resource-based view that considers ITC a scarce resource unevenly distributed across companies. Since information technologies have become more readily available, it is worth reviewing whether ITC firms have shorter financial closing time than their competitors in today's IT environment. For instance, Carr (2003) argued that major advances in information technologies are eroding the competitive edge of IT leaders. Chae et al. (2014) selected IT leaders based on the Information Week 500 rankings from 2001 to 2004 and studied their financial performance measures. He suggests that IT leaders do not seem to outperform matched control samples in financial measures such as returns on assets and equity.

\section{Hypotheses Development}

First, we argue that developing IT capability has a direct impact on financial closing time. IT capability is not merely a result of adopting technologies, but also the ability of companies to integrate the IT in their business processes. In this respect, ITC firms still have the distinct advantage in terms of making technology an integrated part of the business organization despite the wider accessibility of IT software to their competitors. The resource-based view posits that companies must integrate IT with business processes in order to benefit from the implementation of new technologies: IT investment itself might not produce the desired improvements in financial reporting. For example, Marchand and Kettinger (2011) surveyed senior managers (nearly 60\% of whom were CEOs, executive and senior vice presidents and general managers) and reported that they share the view that companies should do more than just excel at investing in and deploying information technology. The senior executives agreed that companies must combine IT with 
capabilities in collecting, organizing and maintaining information. In this regard, firms with superior IT Capabilities (ITC Firms) are better positioned to have a more efficient and effective financial closing time.

The above discussions lead to our first hypothesis:

H1: ITC Firms have shorter financial closing time than their competitors

More recently, the literature also began to use the timing of changes in quarterly earnings as a signal of earnings management (Das et al. 2009). Thus, managers at ITC Firms may be better equipped to exercise their discretions in the financial reporting processes to strategically signal quarterly earnings patterns in the interim periods. For example, anecdotal evidence by investment experts and the financial press suggests the need for alert when there are late-year surges in revenue. Thus, the management will try to avoid such a late-year earnings reversal and smooth out earnings across the fiscal quarters. In summary, we posit that companies with advanced IT capabilities will be more resourceful in their internal reporting and forecasting processes to avoid showing abrupt changes to external capital market participants toward fiscal year end. This leads to a reduced probability of a fourth-quarter earnings reversal.

Therefore, we state our second hypothesis as

H2: ITC firms are less likely to exhibit fourth-quarter earnings reversals than their competitors

\section{RESEARCH DESIGN}

The InformationWeek 500 (IW500) ranking index between 2005 and 2012 are collected as the empirical proxy for superior IT capability. IW500 is compiled by a group of experts including business executives, IT practitioners and information systems researchers. IW500 firms must manifest the ability to integrate IT in the architecture and infrastructure of an organization. Table 1 illustrates the sample selection process. Firms listed in IW500 from 2005 to 2012 are manually matched with their top competitors (up to three) based on the Hoover's Directory. These competitors are selected in terms of size and industry as the IW500 firms (Weston, 2007). We then use the following regression model to test $\mathrm{H} 1$ :

$F C T=\delta_{0}+\delta_{1} I T C+\delta_{2} E S U R P+\delta_{3} I T C * E S U R P+\delta_{4} L G T A+\delta_{7} A U D O P N+\varepsilon$

In the above regression model, FCT is the time lag between fiscal year end and earnings announcement date, and ITC is as an indicator variable to equal one if a firm is on the InformationWeek 500 list and zero otherwise. The model also controls for known significant determinants of reporting lag identified in the literature. The size of the company is captured by the variable $L G T A$, which is the natural $\log$ of total assets. AUDOPN is a binary variable controlling for whether the opinion in an annual independent audit report is qualified, which may signal underlying deficiencies in the financial reporting processes and delay a firm's financial closing time (i.e. Keller 1986). Earnings surprise (ESURP) is the difference between actual earnings per share and market expectation, scaled by the magnitude of market expectation. Firms with a positive earnings surprise may be more inclined to close their books and announce their results sooner than those with results below expectations.

\section{ITC and the Logistic Regression Model on Fourth-Quarter Earnings Reversals}

$\operatorname{Prob}(N P / P N)=\beta_{0}+\beta_{1} I T C+\beta_{2} L G T A+\beta_{3} L E V+\beta_{4} M T B+\beta_{5} O C F+\beta_{4} B I G 4+\beta_{5} A U D T E N+\beta_{7} R O A+\varepsilon$

As in equation (1), the major variable of interest is ITC and the probability of late year earnings reversal. $N P / P N$ indicates whether there is a fourth-quarter earnings reversal. A change from negative to positive $(N P)$ can be associated with managers attempting early booking of sales (which might otherwise occur in the following year) and/or underestimating and postponing expenses in the fourth quarter. On the other hand, a change from positive to negative could indicate that managers are increasing reserves toward fiscal year end. A firm's debt leverage $(L E V)$ is another factor that may influence earnings patterns. $O C F$ is quarterly operating cash flows. The market-to-book $(M T B)$ and Return on Assets $(R O A)$ are used as proxies of growth opportunities. AUDTEN is a variable measuring the number of 
years the audit firm has audited the financial statements of the company and BIG4 indicates whether the auditor is one of the Big 4 accounting firms.

\section{EMPIRICAL ANALYSES}

\section{Descriptive Statistics}

It appears that ITC firms have shorter financial closing time, are larger in both assets and market valuation, and less leveraged. The auditors of the ITC firms tend to stay longer and more likely to be Big-4 firms. However, the difference between the financial performances (ROA) of ITC and non-ITC firms does not appear to be significant. We also see a large fluctuation in 2008-2009 where there are more NP changes and less PN changes. This is probably due to the major shift in the business cycle (the "Great Recession") that took place in the period.

\section{Regression Results}

A fixed-effect regression model for a panel data set is utilized for effects of unobserved firm-level characteristics. The results for equation (1) indicate that, on average, ITC firms have a reduced FCT in comparison with their competitors. The negative and significant coefficient on ITC*ESURP indicates that the effect of IT capability on financial closing time is also more pronounced when firms have positive earnings surprises. It supports the idea that ITC firms are able to announce good news earlier.

Table 3 shows the logistic regression results. On average, the probability of negative-to-positive (NP) fourth quarter earnings reversals is lower for ITC firms. This association is statistically and economically significant. On the other hand, there is no statistically significant relationship among ITC firms and downward Positive-to-Negative earnings reversals in the fourth quarter. As discussed earlier, because seasonally adjusted late-year earnings changes, especially upward quarterly reversals, may send a strong signal of earnings management to capital market participants, firms may rely on their IT Capability to spread out the needed adjustment in the interim quarters and thus attenuate signals of earnings reversals in the fourth quarter.

\section{CONCLUDING REMARKS}

Using data from Information Week 500 companies and their top competitors, we find that ITC firms have shorter reporting cycles and financial closing time. There is also a lower probability for ITC firms to have late-year earnings reversals. It seems that ITC firms is better adapted to fine-tune the reporting of operating results and is able to avoid sending out signals that may be considered as a manipulation of quarterly results in financial reporting.

The empirical results of this study contribute to our understanding of the broad impact of organizational IT capability on quarterly financial reporting patterns. However, our work also has several limitations. First, just as other archival measures for earnings management, fourth-quarter earnings reversal can only imply the existence of potential managerial manipulation of earnings and thus is not a definitive measure of earnings management. Second, it would be ideal if researchers could also observe the interactions between the strength of internal controls and IT capability, and how they may affect firms' financial reporting behaviors. Future research may be able to develop new measures of internal control strength to investigate the relationship between ITC and signals of earnings management one-step further. In addition, there may be informal IT systems existing within the enterprise environment but beyond formal IT controls' reach (Curits and Debreceny 2014). This further illustrates the need of future research to develop in-depth case studies that may complement our understanding on the relationship between ITC and financial reporting behaviors. 
Table 1. Descriptive Statistics $(n=7,584)$

\begin{tabular}{l|c|c|c|c|c|c|c}
\hline & \multicolumn{3}{|c|}{ ITC Firms } & \multicolumn{3}{c|}{ Competitors } & t-statistics \\
\hline \multicolumn{1}{c|}{ Variable } & Mean & Median & Std. Err. & Mean & Median & Std Err. & \\
\hline FCT & 40.17 & 36.00 & 28.97 & 44.47 & 40.00 & 32.98 & -5.59 \\
\hline LGTA & 8.971 & 8.843 & 1.957 & 8.658 & 8.596 & 1.944 & 5.41 \\
\hline OCF & 0.223 & 0.089 & 6.294 & 0.135 & 0.083 & 1.086 & 0.56 \\
\hline LEV & 0.222 & 0.194 & 0.178 & 0.251 & 0.215 & 0.199 & -5.38 \\
\hline MTB & 3.346 & 2.081 & 7.133 & 2.896 & 1.964 & 7.356 & 2.09 \\
\hline BIG4 & 0.975 & 1.000 & 0.155 & 0.939 & 1.000 & 0.240 & 6.68 \\
\hline AUDTEN & 24.397 & 24.000 & 12.174 & 23.701 & 23.000 & 11.354 & 2.31 \\
\hline ROA & 0.089 & 0.044 & 1.598 & 0.051 & 0.040 & 0.564 & 1.29 \\
\hline
\end{tabular}

$F C T=$ financial closing time and is measured as the time lag (in days) between fiscal year end and earnings announcement date

$E S U R P=$ difference between actual earnings and market expectation of earnings, scaled by the market expectation

LGTA=natural log of total assets

$\mathrm{OCF}=$ operating cash flows, scaled by lagged total assets

$\mathrm{LEV}=$ total debts divided by total assets

MTB=market to book value of equity

BIG4=1 if the firm engaged a Big 4 auditor, and 0 otherwise

AUDTEN=auditor tenure

ROA=Return on assets

\begin{tabular}{|c|c|c|}
\hline & NP & PN \\
\hline 2005 & $\begin{array}{c}105 \\
(11.08 \%)\end{array}$ & $\begin{array}{c}175 \\
(18.46 \%)\end{array}$ \\
\hline 2006 & $\begin{array}{c}125 \\
(13.19 \%)\end{array}$ & $\begin{array}{c}138 \\
(14.56 \%)\end{array}$ \\
\hline 2007 & $\begin{array}{c}94 \\
(9.92 \%)\end{array}$ & $\begin{array}{c}203 \\
(21.41 \%)\end{array}$ \\
\hline 2008 & $\begin{array}{c}98 \\
(10.34 \%)\end{array}$ & $\begin{array}{c}177 \\
(18.67 \%)\end{array}$ \\
\hline 2009 & $\begin{array}{c}274 \\
(28.90 \%)\end{array}$ & $\begin{array}{c}66 \\
(6.96 \%)\end{array}$ \\
\hline 2010 & $\begin{array}{c}99 \\
(10.44 \%)\end{array}$ & $\begin{array}{c}181 \\
(19.09 \%)\end{array}$ \\
\hline 2011 & $\begin{array}{c}107 \\
(11.29 \%)\end{array}$ & $\begin{array}{c}170 \\
(17.93 \%)\end{array}$ \\
\hline 2012 & $\begin{array}{c}131 \\
(13.82 \%)\end{array}$ & $\begin{array}{c}170 \\
(17.93 \%)\end{array}$ \\
\hline
\end{tabular}

NP (Negative-to-Positive) and PN (Positive-to-Negative) are late-year (4th quarter) earnings reversals.

Table 2. Fixed-Effects Model on Firm IT Capability and FCT

$F C T=\delta_{0}+\delta_{1} I T C+\delta_{2} E S U R P+\delta_{3} I T C * E S U R P+\delta_{4} L G T A+\delta_{7} A U D O P N+\varepsilon$

\begin{tabular}{l|c|c|c}
\hline & Coefficient & Standard Deviation & p value \\
\hline ITC & -4.0123 & 0.6737 & $<0.001$ \\
\hline ESURP & -1.1458 & 0.4391 & $<0.001$ \\
\hline ESURP*ITC & -0.9284 & 0.4391 & 0.02 \\
\hline LGTA & -3.1681 & 0.1585 & $<0.001$ \\
\hline AUDITOP & 1.3899 & 0.0623 & 0.02 \\
\hline Adj. R $^{2}$ & 0.081 & & \\
\hline
\end{tabular}

$2005-2012, \mathrm{n}=7,584$. 
Table 3. Logistic Regression Analysis on ITC and Last-Quarter Earnings Reversals $\operatorname{Prob}(N P / P N)=\beta_{0}+\beta_{1} I T C+\beta_{2} L G T A+\beta_{3} L E V+\beta_{4} M T B+\beta_{5} O C F+\beta_{4} B I G 4+\beta_{5} A U D T E N+\beta_{7} R O A+\varepsilon$

\begin{tabular}{l|c|c|c|c}
\hline & \multicolumn{2}{|c}{ NP (Negative-to-Positive) } & \multicolumn{2}{c}{ PN (Positive-to-Negative) } \\
\hline ITC & Estimate & p value & Estimate & p value \\
\hline LGTA & -0.3158 & 0.0390 & 0.0694 & 0.6338 \\
\hline LEV & 0.0038 & 0.3243 & -0.0464 & 0.2131 \\
\hline MTB & 0.3809 & 0.0859 & 0.1493 & 0.6942 \\
\hline OCF & -0.0183 & 0.1025 & -0.0009 & 0.8010 \\
\hline BIG4 & 0.9470 & 0.4264 & -1.5724 & 0.1238 \\
\hline AUDTEN & -0.0897 & 0.8754 & 0.3835 & 0.5481 \\
\hline ROA & -0.0211 & 0.0008 & 0.004 & 0.3879 \\
\hline
\end{tabular}

\section{AUTHOR BIOGRAPHIES}

Mingjun Zhou is at the School of Accountancy \& Management Information Systems at DePaul University.

Miguel Aguirre-Urreta is at the Department of Information Systems and Business Analytics, Florida International University and the faculty director of Innovation Hub.

\section{REFERENCES}

Becker, C.L., DeFond, M.L., Jiambalvo, J., \& Subramanyam., K.R. (1998). The effect of audit quality on earnings management. Contemporary Accounting Research, 15(1), 1-21.

Bharadwaj, A. (2000). A resource-based perspective on information technology capability and firm performance: An empirical investigation. MIS Quarterly, 14(1), 169-196.

Brazel, J. F. \& Dang, L. (2008). The effect of ERP system implementations on the management of earnings and earnings release dates. Journal of Information Systems, 22(2), 1-21.

Burgstahler, D. \& Dichev, I. (1997). Earnings Management to avoid earnings decreases and losses. Journal of Accounting and Economics, 33(2), 387-413.

Carr, N. G. (2003). IT doesn't matter. Harvard Business Review, 81(5), 41-49.

Chae, H-C., Chang, K.E., \& Prybutok, V.R (2014). Information technology capability and firm performance: contradictory findings and their possible causes. MIS Quarterly, 38(1), 301-325.

Chen, Y., A. Smith, A., Cao, J., \& Xia, W. (2014). Information technology capability, internal control effectiveness, and audit fees and delays. Journal of Information Systems, 28(2), 149-180.

Curtis, M. \& Debreceny, R. (2015). Challenges from and to the senior editors of the Journal of Information Systems (Editorial). Journal of Information Systems. Spring 2015.

Das, S., Shroff, P., \& Zhang, H. (2009). Quarterly earnings patterns and earnings management. Contemporary Accounting Research, 26(3), 797-831.

Dechow, P. M., Sloan, R.G., \& Sweeney, A.P. (1995). Detecting earnings management. The Accounting Review, 70(April), $193-225$.

DeFond, M. L. \& Jiambalvo, J. (1993). Debt covenant violation and manipulation of accruals. Journal of Accounting and Economics 17, $145-176$.

Dehning. B., \& Richardson, V.J. (2002). Returns on investments in information technology: A research synthesis. Journal of Information Systems, 16(1), 7-30.

Keller, S. B. (1986). Reporting timeliness in the presence of subject to audit qualifications. Journal of Business Finance \& Accounting, 13(1), 117-124.

Lee, H., Made, V., \& Son, M. (2008). A comparison of reporting lags of multinational and domestic firms. Journal of International Financial Management and Accounting, 19(1), 28-56.

Leventis, S., \& Weetman, P. (2004). Timeliness of financial reporting: applicability of disclosure theories in an emerging capital market. Accounting and Business Research, 34(1), 43-56.

Marchand D.A. \& Kettinger, W.J. (2011) Information orientation (IO): how effective information use drives business performance. SISTEMAS 120(75-84).

Morris, J. \& Laksmana., I. (2010). Measuring the impact of enterprise resource systems on earnings management. Journal of Emerging Technologies in Accounting (7), 47-71.

Stratopoulos, T.C., Vance, T.W., \& Zou, X. (2013). Incentive effects of enterprise systems on the magnitude and detectability of reporting manipulations. International Journal of Accounting Information Systems, 14(39-57).

Tam, K.Y. (1998). The impact of information technology investments on firm performance and evaluation: Evidence from newly industrialized economies. Information Systems Research, 9(1), 85-98.

Weston, R. (14 September, 1998). Where to find innovators. InformationWeek. Retrieved from www.informationweek.com/700/method.htm). 